\title{
Optimalisasi Pengelolaan Pertanian Terpadu Guna Mendukung Terwujudnya Desa Mandiri Energi di Desa Sokawera, Kabupaten Banyumas
}

\section{(Optimization of Integrated Agricultural Management to Support the Establishment of an Energy Self-Sufficient Village in Sokawera Village, Banyumas District)}

\author{
Ida Widiyawati ${ }^{1}$, Sapto Nugroho Hadi ${ }^{*}$, Furqon ${ }^{2}$, Ahmad Fauzi ${ }^{1}$, Wilis Cahyani ${ }^{1}$ \\ ${ }^{1}$ Jurusan Agroteknologi, Fakultas Pertanian, Universitas Jenderal Soedirman, Jalan Soeparno No. 61, Purwokerto Utara, \\ Banyumas, Jawa Tengah 53122. \\ 2 Jurusan Teknologi Pertanian, Fakultas Pertanian, Universitas Jenderal Soedirman, Jalan Soeparno No. 61, Purwokerto \\ Utara, Banyumas, Jawa Tengah 53122. \\ *Penulis Korespondensi: sapto.hadi@unsoed.ac.id \\ Diterima September 2019/Disetujui Maret 2020
}

\begin{abstract}
ABSTRAK
Sebagian besar penduduk di Desa Sokawera bekerja sebagai peternak dan petani. Angka pendapatan penduduk tergolong rendah, rata-rata kurang dari Rp 10.000/kapita/hari. Terdapat potensi lokal yang belum secara optimal dikelola di Desa Sokawera, yaitu peternakan sapi mandiri dan perkebunan kelapa rakyat. Tujuan kegiatan ini adalah melakukan pemberdayaan masyarakat untuk optimalisasi pengelolaan pertanian terpadu ramah lingkungan bersumber potensi lokal guna mendukung terwujudnya desa mandiri energi. Strategi yang digunakan dalam kegiatan ini melalui pendekatan PRA (Partisipatory Rural Appraisal) melalui metode pendidikan, pelatihan, pembuatan lahan demonstrasi dan plot (demplot), dan pendampingan serta dilengkapi dengan teknik belajar sambil bekerja (learning by doing). Kegiatan ini diawali dari pelaksanaan kegiatan penyuluhan dan transfer pengetahuan tentang manfaat pertanian terpadu ramah lingkungan, pelatihan pembuatan dan pemanfaatan sumber daya lokal untuk mendukung optimalisasi pengelolaan sistem pertanian terpadu ramah lingkungan seperti kotoran ternak menjadi biogas, limbah biogas menjadi pupuk organik cair (POC) dan pupuk organik padat (POP), dan limbah tempurung kelapa menjadi biopestisida asap cair, pelatihan pembuatan demplot, budi daya sayuran sehat, pelatihan pengolahan produk pertanian lokal menjadi produk jadi bernilai tambah, dan pelatihan strategi pemasaran produk melalui desain dan pembuatan kemasan produk yang menarik. Kegiatan ini memberikan pengetahuan dan keterampilan kepada masyarakat sasaran tentang pengelolaan potensi lokal seperti limbah kotoran sapi dan tempurung kelapa untuk optimalisasi pertanian terpadu ramah lingkungan. Kegiatan ini juga menjadi titik awal untuk terwujudnya desa mandiri energi. Biogas yang diproses dari kotoran ternak berhasil digunakan untuk pengganti gas elpiji.
\end{abstract}

Kata kunci: asap cair, biogas, pertanian terpadu, Sokawera

\begin{abstract}
Most residents in Sokawera Village work as farmers. Population income figures are relatively low, averaging less than IDR 10,000/capita/day. Sokawera village has local potentials that have not been optimally managed, namely independent cattle farms and smallholder coconut plantations. This activity aims is to empower the community to optimize the management of eco-friendly integrated agriculture sourced from local potential to support the realization of an energy self-sufficient village. The strategy used in this activity is through the PRA (Participatory Rural Appraisal) approach through the methods of education, training, demonstration plots, and assistance and are equipped with learning techniques while working (learning by doing). This activity began with the implementation of extension activities and transfer of knowledge about the benefits of eco-friendly integrated agriculture, training on the making and utilization of local resources to support the optimization of the management of eco-friendly integrated farming systems such as cattle dung into biogas, biogas waste into liquid and solid organic fertilizers, and coconut shell waste into liquid smoke biopesticides, training in making demonstrations and plots (demonstration plots) of healthy vegetable cultivation, training in processing local agricultural products into value-added products, and training in product marketing strategies through the design and manufacture of attractive product packaging. This activity provides knowledge and skills to the target community regarding the management of local potentials such as cow dung waste and coconut shell to optimize environmentally-friendly integrated agriculture. This activity is also a starting point for the realization of an
\end{abstract}


energy self-sufficient village. Biogas which is processed from livestock manure is used successfully to replace LPG.

Keywords: biogas, integrated agriculture, liquid smoke, Sokawera

\section{PENDAHULUAN}

Minyak bumi menjadi salah satu energi yang paling banyak digunakan oleh masyarakat untuk memenuhi berbagai macam kebutuhan hidup sehari-hari seperti bahan bakar kendaraan, pembangkit listrik, dan kegiatan rumah tangga seperti memasak. Minyak bumi yang digunakan untuk memasak disebut dengan Liquid Petroleum Gas (LPG). Konsumsi LPG di Indonesia selama hampir dua dekade semakin meningkat. Penggunaan LPG rumah tangga pada tahun 2000 mencapai 696.000 ton, lalu pada tahun 2010 naik mencapai 3.564.000 ton, dan tahun 2018 mencapai 7.252.000 ton (Kementerian ESDM 2018). Kenaikan jumlah permintaan LPG disebabkan adanya himbauan untuk pergantian minyak tanah menjadi LPG. Namun masih kurangnya kesiapan produksi LPG di tanah air menyebabkan terjadinya impor LPG mencapai 1 juta ton pada tahun 2010 (Kementerian ESDM 2011).

Keterbatasan persediaan LPG mendorong banyak pihak untuk mencari alternatif penggunaan bahan bakar yang lebih murah dan dapat diperbaharui, yaitu seperti penggunaan biogas. Biogas merupakan gas alam yang dihasilkan dari aktivitas anaerobik atau fermentasi dari bahanbahan organik seperti kotoran manusia, hewan, limbah domestik, atau sampah yang dapat terurai. Penggunaan biogas dapat mengurangi emisi gas rumah kaca karena gas yang dihasilkan berupa metana $\left(\mathrm{CH}_{4}\right)$ digunakan untuk kebutuhan masyarakat sehingga biogas lebih ramah lingkungan. Kelebihan lain dari biogas adalah dapat menghasilkan panas yang hampir setara dengan LPG, sedangkan kekurangannya adalah dibutuhkan reaktor biogas serta jaringan pipa dari reaktor ke kompor sehingga perlu pemasangan instalasi yang rumit (Widyastuti et al. 2013).

Salah satu sumber potensial penghasil biogas adalah kotoran ternak sapi. Kotoran sapi lebih umum digunakan untuk pembuatan biogas karena mengandung metana $\left(\mathrm{CH}_{4}\right)$ sebesar 55$65 \%$, karbon dioksida $\left(\mathrm{CO}_{2}\right)$ sebesar $30-35 \%$, dan sedikit gas hidrogen $\left(\mathrm{H}_{2}\right)$, gas nitrogen $\left(\mathrm{N}_{2}\right)$, juga memiliki keseimbangan nutrisi yang relatif baik bagi proses biologis (Artayana et al. 2017). Satu ekor sapi setiap harinya dapat menghasilkan kotoran sebanyak $25 \mathrm{~kg}$, apabila suhu digester selalu konstan pada suhu $30^{\circ} \mathrm{C}$ maka setiap $1 \mathrm{~kg}$ dapat dihasilkan $0,3 \mathrm{~m}^{3}$ biogas, sehingga 1 ekor sapi mampu menghasilkan $7,5 \mathrm{~m}^{3}$ biogas atau setara dengan $3,45 \mathrm{~kg}$ LPG karena $1 \mathrm{~m}^{3}$ biogas setara dengan 0,46 kg LPG (Semin et al. 2014).

Desa Sokawera merupakan desa yang terletak di Kecamatan Cilongok, Kabupaten Banyumas, Jawa Tengah. Desa ini memiliki luas wilayah 1008,5 ha dengan tata guna lahan untuk pemukiman, sawah, tegalan, hutan rakyat/kebun, hutan negara dan lainnya. Jumlah penduduk 7.267 jiwa (laki-laki 3.734 jiwa dan perempuan 3.533 jiwa) yang sebagian besar bermatapencaharian sebagai petani dan buruh tani. Terdapat sejumlah permasalahan di Desa Sokawera yang diidentifikasi oleh Pemerintah Kabupaten Banyumas (2018), yaitu pendapatan warga yang rendah (rata-rata kurang dari Rp $10.000 /$ kapita/hari), tingkat pendidikan formal masyarakat rata-rata tamat sekolah dasar, dan banyak pengangguran. Selain itu, kepemilikan lahan sempit (rata-rata kurang dari 0,1 ha), produksi pertanian rendah, sarana produksi pertanian mahal tetapi harga jual pertanian rendah karena kurangnya informasi pasar dan tidak adanya strategi pemasaran yang khusus, penyuluhan pertanian kurang, petani tidak memiliki keterampilan pembibitan tanaman dan penanganan hasil pertanian. Diperlukan upaya penumbuhan kemandirian sumber daya atau sarana produksi pertanian, sehingga usaha tani yang dilakukan oleh petani di Desa Sokawera semakin mandiri dan tidak bergantung pada input dari luar daerah.

Desa Sokawera sebenarnya memiliki potensi dibangun menjadi desa mendiri energi, yaitu sebuah program bagi desa-desa yang berpotensi memenuhi kebutuhan energinya secara mandiri sehingga mampu menciptakan lapangan kerja dan mengurangi angka kemiskinan dengan mendorong kemampuan masyarakat dalam menggunakan sumber daya setempat. Kriteria mendasar dari desa mandiri energi adalah mampu memenuhi $60 \%$ dari total kebutuhan energinya menggunakan energi terbarukan. 
Untuk memenuhi kriteria tersebut maka harus dilakukan perintisan terlebih dahulu dengan memilih desa yang potensial (Juwito \& Haryono 2013).

Desa Sokawera memiliki beberapa potensi yang dapat dikembangkan guna mendukung terwujudnya desa mandiri energi, seperti peternakan sapi mandiri. Terdapat sekitar 10 titik peternakan sapi mandiri dengan kapasitas hewan ternak per kandang bervariasi mulai dari 2-5 ekor di Desa Sokawera. Selama ini, warga yang memiliki sapi hanya memanfaatkan sapi untuk diambil susunya, selain untuk penggemukan bagi keperluan hari raya Idul Qurban. Sementara kotoran sapi yang dihasilkan belum secara baik dimanfaatkan. Apabila dikelola lebih lanjut, kotoran sapi bisa diolah menjadi biogas melalui proses fermentasi. Biogas yang dihasilkan dapat dialirkan ke rumah-rumah warga untuk memenuhi kebutuhan dasar warga tentang energi. Biogas dapat digunakan sebagai bahan pengganti gas LPG atau minyak tanah sebagai bahan bakar kompor di dapur (Oktavia \& Firmansyah 2016). Dengan asumsi kebutuhan rata-rata gas LPG setiap rumah tangga miskin mencapai 1,5 tabung gas LPG $3 \mathrm{~kg}$ atau 4,5 $\mathrm{kg} / \mathrm{bulan} /$ kepala keluarga (KK), maka kebutuhan gas LPG di Desa Sokawera dengan jumlah 1842 KK (Profil Desa Sokaware 2020) mencapai 8.289 $\mathrm{kg} / \mathrm{bulan}$. Apabila dari 10 titik peternakan sapi mandiri berisi rata-rata tiga ekor sapi, maka terdapat sekitar 30 ekor sapi, dengan setiap satu ekor sapi menghasilkan kotoran sapi yang apabila dikonversi setara dengan 3,45 kg LPG maka terdapat potensi 103,4 kg LPG, yang dapat memenuhi kebutuhan energi rumah tangga sekitar 23 KK. Pemanfaatan potensi lokal peternakan sapi mandiri ini dapat turut menjadi langkah awal untuk membantu mewujudkan desa mandiri energi di Desa Sokawera. Belum lagi, limbah biogas yang dihasilkan dapat diproses menjadi pupuk organik cair (POC) dan pupuk organik padat (POP). Kedua pupuk organik ini dapat digunakan untuk optimalisasi pertanian terpadu yang ramah lingkungan (pertanian terintegrasi dengan sistem alami yang mengurangi input pupuk dan pestisida sintetik).

Selain memiliki potensi lokal berupa peternakan sapi mandiri, Desa Sokawera juga memiliki perkebunan rakyat dengan luas 225 ha dan sebagian besar diolah oleh masyarakat setempat dengan menanam pohon kelapa guna untuk diambil air nira dan diolah menjadi gula. Hasil samping produksi gula kelapa dari perkebunan kelapa rakyat adalah tempurung kelapa. Selama ini tempurung kelapa masih menjadi limbah yang tidak dimanfaatkan. Padahal tempurung kelapa bisa diproses menjadi biopestisida asap cair. Biopestisida asap cair juga dapat digunakan untuk pengendalian Organisme Pengganggu Tanaman (OPT) yang merugikan bagi pertanian warga. Biopestisida asap cair ini juga dapat digunakan untuk optimalisasi pertanian terpadu yang ramah lingkungan karena mengurangi penggunaan pestisida sintetik yang cenderung merugikan pertanian di masa depan.

Asap cair (liquid smoke) sebagai salah satu sumber energi terbarukan berbahan baku biomassa seperti tempurung kelapa memiliki peran yang signifikan dalam usaha dimanfaatkan sebagai alternatif kegiatan pertanian. Asap cair tempurung kelapa mengandung senyawa fenol, asam organik, dan alkohol yang berperan sebagai antibakteri dan antimikroba. Oleh karena itu, asap cair berpotensi untuk menangani masalah OPT. Fungsi asam organik sebagai antimikrobia pada asap cair tempurung kelapa mampu membunuh OPT terutama patogen dengan cara mengasamkan sitoplasma, merusak tegangan permukaan membran sel sehingga transport makanan melalui membran menjadi hilang dan menyebabkan ketidakstabilan pada berbagai macam fungsi dan struktur komponen sel. Fungsi fenol sebagai antimikrobia dapat menyerang membran sel sehingga permeabilitas sel terganggu, terjadinya inaktivasi enzim-enzim esensial, kerusakan pada material genetik fungsional, dan rusaknya membran sel karena hidrolisis lipid (Nugroho \& Aisyah 2013).

Melalui pemanfaatan potensi lokal, yang selama ini cenderung menjadi limbah, petani bisa menekan biaya produksi pertanian karena dapat mengalihkan penggunaan pupuk kimia sintetik kepada penggunaan POC atau POP. Petani juga dapat mengalihkan penggunakan pestisida sintetik kepada penggunaan biopestisida asap cair. Kondisi ini pada akhirnya akan meningkatkan pendapatan petani. Kedua potensi lokal yang dimiliki Desa Sokawera menjadi tantangan untuk dapat dioptimalkan secara lebih baik guna peningkatan kesejahteraan warga setempat. Oleh karena itu, perlu dilakukan kegiatan pengabdian kepada masyarakat (PKM). Tujuan kegiatan ini adalah melakukan pemberdayaan masyarakat untuk optimalisasi pengelolaan pertanian terpadu ramah lingkungan bersumber potensi lokal guna mendukung terwujudnya desa mandiri energi. 


\section{METODE PELAKSANAAN KEGIATAN}

\section{Lokasi dan Peserta Kegiatan}

Lokasi kegiatan PKM berada di Desa Sokawera, Kecamatan Cilongok, Kabupaten Banyumas, Provinsi Jawa Tengah. Mitra sasaran kegiatan ini adalah kelompok tani Qoryah Barokah Warohmah, petani gula kelapa, Karang Taruna Tekad Sembada IX, dan wanita petani di Desa Sokawera. Pelaksanaan kegiatan ini dibantu oleh 20 orang mahasiswa dari lintas fakultas di Universitas Jenderal Soedirman.

\section{Bahan dan Alat}

Bahan yang dibutuhkan untuk kegiatan ini adalah limbah kotoran ternak dari peternakan sapi mandiri, tempurung kelapa dari hasil samping pembuatan gula merah, limbah biogas, dan bahan pendukung lainnya. Peralatan yang diperlukan adalah perangkat instalasi biogas dengan kapasitas tabung biodigester sebesar $6,25 \mathrm{~m}^{3}$, perangkat pembuatan biopestisida asap cair dari limbah tempurung kelapa, perangkat pengolahan limbah biogas menjadi POC dan POP, perangkat budi daya tanaman sayuran sehat, perangkat pembuatan desain kemasan produk, dan peralatan pendukung lainnya.

\section{Metode Pelaksanaan Kegiatan}

Strategi yang digunakan dalam kegiatan ini melalui pendekatan PRA (Partisipatory Rural Appraisal) melalui metode pendidikan, pelatihan, demplot, dan pendampingan serta dilengkapi dengan teknik belajar sambil bekerja (learning by doing). Kegiatan ini diawali dari pelaksanaan kegiatan penyuluhan dan transfer pengetahuan tentang manfaat pertanian terpadu ramah lingkungan, pelatihan pembuatan dan pemanfaatan sumber daya lokal untuk mendukung optimalisasi pengelolaan sistem pertanian terpadu ramah lingkungan seperti kotoran ternak menjadi biogas, limbah biogas menjadi POC dan POP, dan limbah tempurung kelapa menjadi biopestisida asap cair, pelatihan budi daya sayuran sehat, pelatihan pengolahan produk pertanian lokal menjadi produk jadi bernilai tambah, dan pelatihan strategi pemasaran produk melalui desain dan pembuatan kemasan produk yang menarik.

\section{Metode Pengumpulan Data}

Metode penngumpulan data yang digunakan adalah studi literatur, wawancara, observasi, dan studi dokumentasi.

\section{Pengolahan dan Analisis Data}

Pengolahan dan analisis data menggunakan metode deskriptif kualitatif dan reduksi data.

\section{HASIL DAN PEMBAHASAN}

Pemberdayaan masyarakat adalah proses pembangunan yang dimulai dari inisiatif masyarakat untuk melakukan proses kegiatan sosial guna memperbaiki situasi dan kondisi diri sendiri. Pemberdayaan masyarakat mutlak memerlukan partisipasi masyarakat sasaran. Tujuan yang ingin dicapai dari pemberdayaan masyarakat adalah membentuk individu dan masyarakat menjadi mandiri. Kemandirian tersebut meliputi kemandirian berpikir, bertindak, dan mengendalikan perilaku. Kegiatan yang dilakukan diharapkan dapat memberdayakan peternak sapi dan kelompok wanita tani, serta masyarakat secara umum yang ada di Desa Sokawera, Kecamatan Cilongok, Kabupaten Banyumas.

\section{Penyuluhan Manfaat Pertanian Terpadu Ramah Lingkungan}

Kegiatan penyuluhan pertanian terpadu dilakukan bersama 25 orang anggota kelompok tani Desa Sokawera. Penyuluhan berisi pengetahuan dan gambaran tentang pertanian terpadu dengan konsep alami atau ramah lingkungan (Gambar 1). Pada kegiatan ini dihadirkan seorang akademisi sekaligus praktisi pertanian terpadu ramah lingkungan (pertanian organik) dari Fakultas Pertanian Universitas Jenderal Soedirman, yaitu Ahadiyat Yugi Rahayu, D.Tech.Sc. Pada forum ini, kelompok masyarakat sasaran diberikan perbandingan penerapan konsep pertanian terpadu di berbagai negara dan manfaat yang didapatkan masyarakat setempat. Secara umum masyarakat memberikan respons yang baik

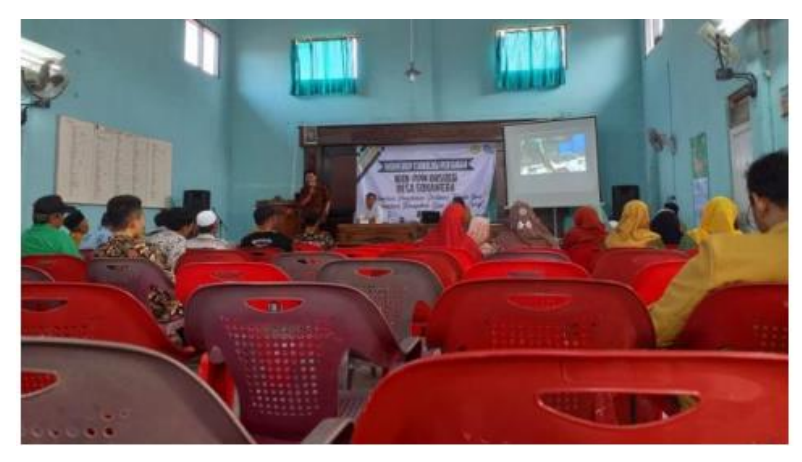

Gambar 1 Penyuluhan pertanian terpadu ramah lingkungan. 
terhadap kegiatan penyuluhan yang dilaksanakan. Meskipun hasil observasi selama forum berlangsung menunjukkan hanya sekitar 20\% masyarakat berencana akan mencoba menerapkan pengetahuan yang didapat dari penyuluhan melalui aplikasi secara langsung. Sementara sebagian besar peserta terkendala karena tidak memiliki lahan pertanian sendiri. Mereka ini hanya bekerja sebagai buruh tani yang dibayar harian.

Kegiatan penyuluhan ditindaklanjuti dengan melaksanakan pendampingan demonstrasi praktik-praktik sederhana selama 35 hari. Kegiatan diikuti oleh seluruh peserta, baik petani pemilik lahan maupun buruh tani. Kegiatan pendampingan demonstrasi praktik meliputi pengenalan pembuatan POP dan POC secara mandiri, aplikasi POP dan POC dalam budi daya sayuran organik, pengendalian hama terpadu dengan pemanfaatan bahan ramah lingkungan (biopestisida dari asap cair tempurung kelapa), dan pascapanen produk pertanian agar memiliki nilai tambah ekonomi.

\section{Pembuatan Instalasi Biogas dan Pemanfaatannya}

Pembuatan instalasi biogas merupakan tahap awal bagi optimalisasi pengelolaan pertanian terpadu. Instalasi biogas akan mengolah limbah kotoran ternak sapi menjadi gas. Sementara limbah yang dihasilkan melalui kegiatan ini, diproses menjadi POC dan POP. Kedua pupuk organik ini akan diaplikasikan pada sistem pertanian berbasis pertanian terpadu yang ramah lingkungan. Gambar 2 menunjukkan pembuatan instalasi biogas.

Metode pembuatan biogas yang akan digunakan adalah metode tabung. Metode ini dipilih karena kapasitas kotoran ternak yang dibutuhkan tidak besar (kurang dari 10 ekor) dan biaya yang dibutuhkan relatif murah. Instalasi biogas ini merupakan penggabungan antara fixed dome untuk digester dan floating drum untuk penampung gas. Ukuran tangki digester disesuaikan dengan kebutuhan keluarga tani dan kapasitas kotoran ternak yang dihasilkan. Untuk menghasilkan gas sebanyak $1 \mathrm{~m}^{3} /$ hari dibutuhkan 2-3 ekor sapi dewasa dengan kapasitas tabung biodigester sebesar $6,25 \mathrm{~m}^{3}$. Kotoran sapi dari kandang diencerkan terlebih dulu untuk kemudian dialirkan ke dalam biodigester dan ditambahkan starter dan rumen agar terjadi fermentasi. Gas yang pertama terbentuk perlu dibuang karena gas tersebut adalah $\mathrm{CO}_{2}$, setelah 14 hari barulah gas yang dihasilkan dapat digunakan untuk bahan bakar kompor gas yang dialirkan langsung ke rumah-rumah.

Kegiatan ini menyasar pada kelompok tani Qoryah Barokah Warohmah dan Bapak Kya'i Ma'aruf terlebih dahulu sebagai mitra dan perintis awal instalasi biogas di Desa Sokawera. Pemasangan instalasi biogas di rumah mitra berlangsung selama 35 hari dimulai dari proses perancangan desain instalasi (Gambar 3), menyusun rangkaian instalasi, penggabungan rangkaian instalasi, dan uji coba pemasangan instalasi. Hasil uji coba menunjukkan bahwa instalasi biogas mampu memenuhi kebutuhan dua rumah warga di sekitar lokasi instalasi biogas, sedangkan untuk instalasi kedua mampu memenuhi kebutuhan bahan bakar pesantren yang dikelola mitra. Memang hasil ini masih jauh dari potensi yang bisa dihasilkan apabila semua peternakan sapi mandiri di Desa Sokawera dapat menggunakan konsep instalasi biogas, namun hasil yang didapat menjadi titik awal yang bisa menjadi percontohan bagi warga lain yang memiliki peternakan sapi mandiri. Dengan pemanfaatan limbah kotoran ternak di dua lokasi, penggunaan gas untuk keperluan dua rumah tangga dan satu pesantren dapat tercukupi.

\section{Pelatihan Pembuatan Pupuk Organik dan Aplikasinya}

Limbah biogas berupa padatan dan cairan diproses menjadi POC dan POP. Pembuatan POC menurut Habibah \& Wahdi (2019) dimulai dengan mencampurkan $20 \mathrm{~L}$ limbah cair biogas
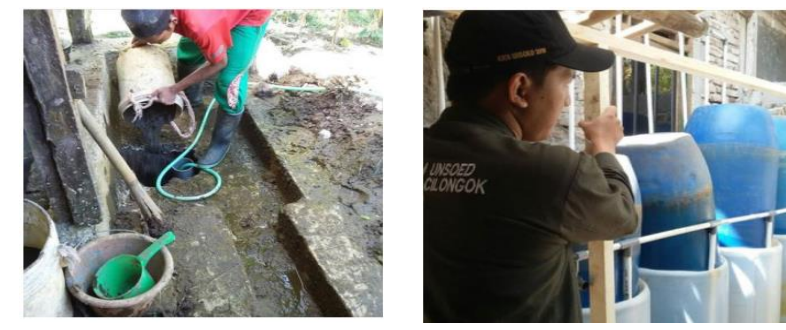

Gambar 2 Pembuatan instalasi biogas.

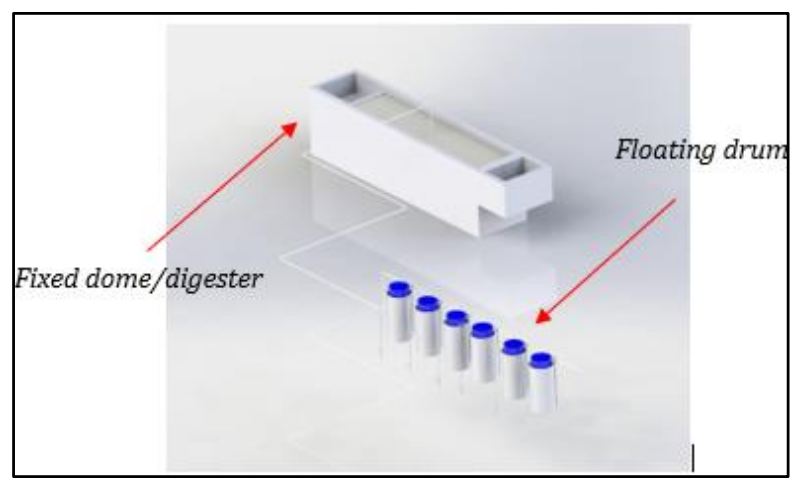

Gambar 3 Desain instalasi biogas. 
dalam jerigen dengan $400 \mathrm{~mL}$ mikroorganisme EM4, dan $400 \mathrm{~mL}$ tetes gula (molase). Campuran juga bisa ditambahkan ekstrak rempah-rempah seperti temulawak, daun sirih, kunyit, lengkuas, serai, dan tembakau. Jerigen ditutup dengan kertas payung cokelat berlapis plastik, kemudian diaduk. Proses fermentasi dilakukan selama 14 hari dan selama proses fermentasi jerigen setiap hari diaduk dan dibuka tutupnya untuk membuang gas yang terbentuk. Pembuatan POP dimulai dengan mencampurkan $1 \mathrm{~kg}$ limbah biogas padat dalam ember dengan $250 \mathrm{~g}$ bekatul, $250 \mathrm{~g}$ kapur, $250 \mathrm{~g}$ abu, dan $250 \mathrm{~g}$ sekam. Bahan kering dicampur dengan $250 \mathrm{~mL}$ larutan air yang sudah dicampur dengan 1 tutup botol mikroorganisme EM4 dan diaduk merata hingga seluruh bahan lembab. Ember ditutup dengan plastik dan disimpan selama 7-14 hari dan secara rutin setiap pagi dan sore diaduk.

Kegiatan pelatihan pembuatan POC dan POP dilakukan di beberapa lokasi. Kegiatan dilaksanakan selama 14 hari dan dihadiri total 149 peserta yang rata-rata merupakan anggota Kelompok Wanita Tani (KWT) binaan PKK desa serta kader PKK. Kegiatan pelatihan dibarengi dengan penyampaian materi tentang proses pengambilan limbah biogas dari peternakan sapi dan cara aplikasi POC dan POP pada demplot pertanian terpadu ramah lingkungan. POC dan POP dapat dijadikan input pertanian sehingga dapat mengurangi penggunaan pupuk kimia sintetik yang untuk jangka panjang dapat merusak lingkungan pertanian. Hasil wawancara dengan masyarakat diperoleh sekitar 32\% peserta tertarik untuk membuat POC dan POP secara mandiri karena memiliki hewan ternak dan sering kebingungan untuk memanfaatkan limbahnya, sedangkan sisanya belum tertarik membuat POC dan POP karena tidak memiliki hewan ternak serta kesulitan akses beberapa bahan-bahan pendukung pembuatan POC dan POP. Untuk mensiasati kesulitan bahan-bahan penunjang pembuatan POC dan POP, tim PKM memberikan alternatif pembuatan POP dari sisa makanan atau limbah dapur yang ditambahkan mikroroganisme EM4 dan gula merah. Harapannya, peserta dapat mudah membuatnya secara mandiri.

\section{Pelatihan Pembuatan Biopestisida Asap Cair dan Aplikasinya}

Tempurung kelapa diproses menjadi arang melalui proses pembakaran. Asap dari pembakaran tersebut dapat diubah menjadi produk cair (asap cair) melalui teknologi pembakaran (pirolisis) dan pengembunan (kondensasi). Melalui teknologi ini dapat dihasilkan asap cair, tar, dan arang dengan perbandingan 45, 10, dan 45\% (Tim Pengkajian Bioindustri Kelapa 2015). Asap cair memiliki beragam manfaat, salah satunya dijadikan sebagai biopestisida dalam upaya pengendalian OPT. Menurut Harsono (2018), asap cair memiliki manfaat sebagai anti bakteri dan anti jamur.

Pada budi daya tanaman, biopestisida asap cair dapat dijadikan sebagai alternatif pestisida yang efektif dan ramah lingkungan. Pada tanaman kakao dilaporkan bahwa penggunaan asap cair tempurung kelapa dapat menghambat pertumbuhan jamur Phytoptora sp. sebesar 50\% (Pangestu et al. 2014). Jamur tersebut juga sering menyerang tanaman hortikultura dan sayuran, sehingga dalam budi daya sayuran organik sangat tepat apabila menggunakan asap cair sebagai pestisida nabati.

Desa Sokawera memiliki potensi pembuatan asap cair dari tempurung kelapa untuk menggantikan pestisida kimia sintetik yang selama ini digunakan untuk pengendalian OPT. Desa Sokawera memiliki total lahan perkebunan sebanyak 225 ha dan sebagian besar digunakan untuk menanami pohon kelapa. Air nira dari pohon kelapa dimanfaatkan sebagai bahan baku gula merah dan gula kristal, sedangkan dagingnya diolah untuk kebutuhan pangan. Tempurung kelapa berdasarkan hasil observasi masih sering dibuang sehingga jumlah limbah tempurung kelapa Desa Sokawera cukup banyak. Limbah tempurung kelapa dapat digunakan sebagai bahan baku pembuatan asap cair.

Pembuatan instalasi asap cair membutuhkan waktu sekitar 30 hari dari mulai pembuatan desain, penyuluhan kepada masyarakat, perakitan instalasi, hingga uji coba yang berlokasi di rumah mitra kelompok tani Qoryah Barokah Warohmah. Pembuatan asap cair tempurung kelapa dilakukan dengan memasukkan tempurung kelapa yang sudah dijemur terlebih dahulu hingga kering ke dalam ruang pemanasan, kemudian hasil kondensasi tempurung kelapa akan mengalami proses pirolisis, kemudian masuk ke dalam pipa penyaluran dan berakhir di ruang pendinginan.

Pada awal pelatihan pembuatan asap cair, lebih dari $90 \%$ warga kurang memahami bahwa limbah tempurung kelapa dapat dimanfaatkan untuk pembuatan asap cair yang berperan sebagai biopestisida. Warga kurang memahami cara kerja instalasi pembuatan asap cair, bagaimana aplikasinya, dan apa manfaatnya bagi 
pertanian. Gambar 4 menunjukkan desain instalasi pembuatan asap cair. Agar kegiatan pengabdian masyarakat berjalan lebih optimal, kegiatan pelatihan diberikan kembali dengan penambahan materi berupa demonstrasi perbandingan aplikasi asap cair sebagai biopestisida pada budi daya tanaman kangkung secara organik (Gambar 5). Melalui kegiatan demonstrasi langsung aplikasi penggunaan asap cair tempurung kelapa, warga dapat memahami bahwa tanaman kangkung yang tidak diaplikasikan asap cair lebih mudah dan banyak diserang OPT, sementara tanaman kangkung yang diberikan aplikasi asap cair hanya sedikit diserang OPT. Dengan demikian seluruh peserta yang hadir dalam pelatihan dapat memahami manfaat penggunaan asap cair sebagai biopestisida yang cukup efektif dalam pengendalian OPT pada tanaman sayuran khususnya kangkung.

Melalui kegiatan ini diharapkan, masyarakat sadar bahwa sumber daya lokal berupa tempurung kelapa yang selama ini dianggap limbah dapat diproses menjadi biopestisida. Dengan pemanfaatan biopestisida dari limbah pertanian lokal, masyarakat sasaran dapat mulai mengurangi kebergantungan kepada penggunaan pestisida sintetik dalam sistem budi daya tanaman pertaniannya.

\section{Demplot Tanaman Sayuran Sehat}

Demplot tanaman sayuran sehat merupakan bagian dari optimalisasi pengelolaan pertanian terpadu ramah lingkungan. Melalui demplot ini, masyarakat sasaran dapat melihat tingkat keberhasilan penggunaan sumber daya lokal (POC, POP, dan biopestisida asap cair) dalam budi daya tanaman sayuran yang sehat karena menghindari penggunaan pupuk dan pestisida kimia sintetik. Tanaman budi daya yang digunakan dalam demplot tanaman sayuran sehat adalah kangkung dan caisim. Materi penyuluhan yang diberikan kepada masyarakat berupa cara mengolah tanah, membuat lubang tanam, menanam bibit tanaman, menyiram tanaman, aplikasi POC dan POP, dan mengendalikan hama dan penyakit menggunakan biopestisida asap cair. Masyarakat dikenalkan dengan sistem budi daya pertanian organik (alami) sehingga produk sayuran yang dihasilkan bisa lebih sehat. Gambar 6 menunjukkan pelatihan budidaya tanaman sayuran organik.

\section{Pelatihan Budi Daya Sayuran Organik}

Agar pengelolaan pertanian terpadu ramah lingkungan lebih optimal berjalan, masyarakat sasaran diberikan pelatihan budi daya sayuran organik setelah diberi penyuluhan mengenai demonstrasi dan plot (demplot). Kegiatan budi daya sayuran organik dimulai dari penyuluhan budi daya sayuran sehat yang merupakan kegiatan pemberian materi dan contoh/praktik langsung kepada warga desa terutama ibu-ibu mengenai pentingnya sayuran bebas pestisida kimia sintetik. Kegiatan ini berlangsung selama 21-28 hari dari awal penanaman hingga panen sayuran. Budi daya sayuran organik sangat tepat dilakukan di Desa Sokawera. Kondisi geografis (iklim) daerah setempat sesuai untuk pertum-

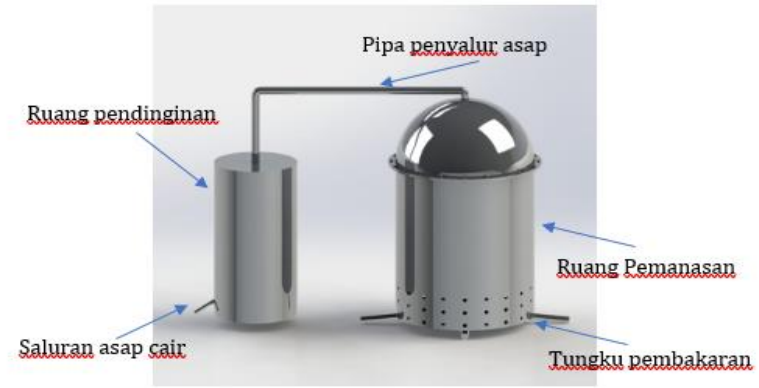

Gambar 4 Desain instalasi pembuatan asap cair.

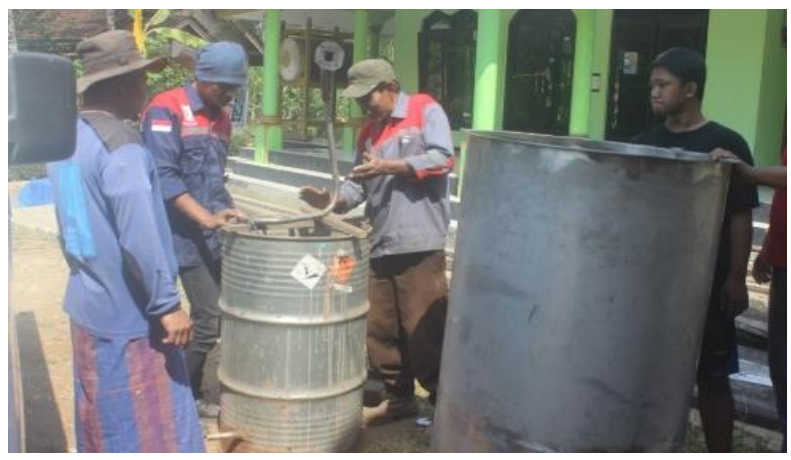

Gambar 5 Perakitan instalasi pembuatan asap cair dari tempurung kelapa.

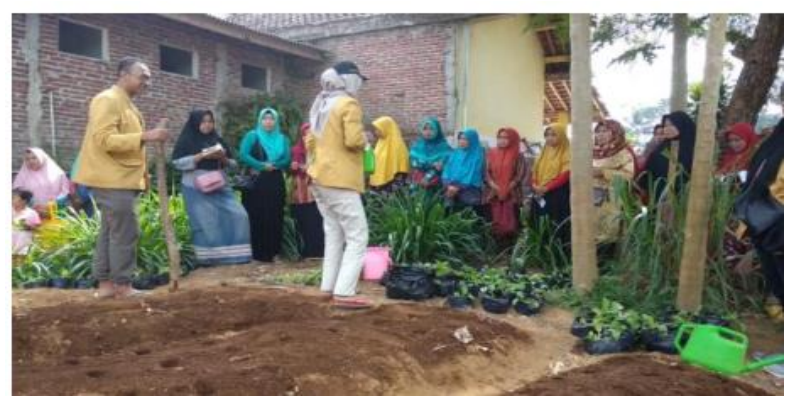

Gambar 6 Pelatihan budi daya tanaman sayuran organik. 
buhan dan perkembangan tanaman sayuran. Dari hasil pengamatan di lapangan, peserta pelatihan sangat antusias mengikuti kegiatan pelatihan. Lebih dari $70 \%$, peserta dapat mengikuti pelatihan dengan baik dan harapannya dapat melakukan teknik budi daya sayuran organik secara mandiri.

\section{Pelatihan Strategi Pemasaran Produk}

Produk yang bernilai jual tinggi, tentunya memiliki kualitas produk yang baik. Selain itu produk tersebut dikemas dengan cara apik dan diberi label menarik. Produk pertanian tidak dijual dalam keadaan mentah tetapi sudah melalui proses pengolahan pascapanen yang baik. Agar produk masyarakat mitra sasaran lebih bernilai jual, maka serangkaian pelatihan strategi pemasaran produk dilakukan. Kelompok sasaran diberikan pelatihan mengenai pentingnya kemasan suatu produk. Kemasan, selain berperan dalam ketahanan produk juga memberikan added value kepada produk tersebut sehingga nilai jualnya menjadi lebih tinggi. Kemasan suatu produk pertanian menurut Darmawan (2017) berperan siginifikan terhadap keputusan konsumen membeli produk tersebut.

Desa Sokawera memiliki beberapa produk pangan berbahan baku singkong untuk diolah menjadi cemilan, seperti keripik mangleng dan cantir, juga sebagai penghasil gula kristal. Produk olahan pangan tersebut masih dijual hanya di sekitar Desa Sokawera saja, karena masih produksi rumah tangga terkecuali gula kristal yang sudah didistribusikan ke koperasi. Olahan pangan dari singkong masih dianggap kurang menjual karena hanya berupa bungkus plastik tanpa keterangan. Pelatihan strategi pemasaran difokuskan pada pengemasan guna meningkatkan nilai jual produk olahan pangan singkong Desa Sokawera. Gambar 7 menunjukkan aneka kemasan dan label produk.

Pelatihan pengemasan berlangsung selama dua hari dan materi yang diberikan terdiri atas pengenalan jenis-jenis kemasan, pengenalan mengenai unsur-unsur label produk, serta cara pembuatan label berbasis aplikasi android dan komputer. Kegiatan ini dihadiri oleh 38 peserta yang terdiri ibu-ibu kader PKK, produsen olahan pangan, serta anggota Karang Taruna Tekad Sembada IX Desa Sokawera. Hasil observasi kegiatan menunjukkan tingginya antusiasme peserta pelatihan ditunjukkan dengan $80 \%$ peserta yang bertanya mengenai kiat-kiat pembuatan kemasan dan label yang baik dan dapat meningkatkan nilai jual produk, serta

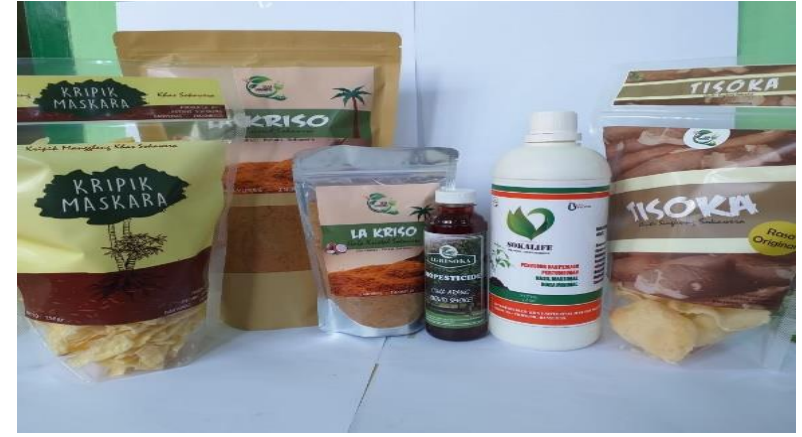

Gambar 7 Aneka kemasan dan label produk.

beberapa peserta juga menanyakan terkait kesempatan distribusi produk diluar Desa Sokawera.

\section{Upaya Pendampingan dan Keberlanjutan}

Meskipun kegiatan ini hanya berlangsung dalam satu tahun, namun tim pengabdian masyarakat berkomitmen mengenai keberlanjutan program di masa depan. Harapannya tentu agar kegiatan ini tidak berhenti di tengah jalan sehingga kurang menghasilkan manfaat dalam jangka panjang. Untuk bisa berjalan secara berkelanjutan, tim secara khusus meminta komitmen mitra sasaran untuk menjaga, memelihara, dan melanjutkan program kerja yang selama ini telah dilakukan. Tim pengabdian akan dengan sangat terbuka memberikan pendampingan dan saran apabila dikemudian hari ada kendala teknis yang ditimbulkan. Kontak person tim pengabdian masyarakat telah diberikan dan dapat diakses kapanpun oleh mitra sasaran. Begitu pula sebaliknya, tim pengabdian masyarakat memiliki kontak person para koordinator mitra sasaran yang dapat digunakan untuk monitoring keberlanjutan program.

\section{SIMPULAN}

Serangkaian kegiatan pengabdian masyarakat telah dilaksanakan untuk mencapai tujuan kegiatan berupa pemberdayaan masyarakat dengan pemanfaatan sumber daya lokal potensial seperti limbah kotoran ternak sapi dan tempurung kelapa. Limbah kotoran sapi diolah menjadi biogas untuk memenuhi kebutuhan dua rumah tangga dan satu pesantren. Limbah biogas diolah menjadi POC dan POP yang diaplikasikan pada budi daya tanaman sayuran organik. Limbah tempurung kelapa diolah menjadi biopestisida asap cair yang diaplikasikan untuk pengendalian OPT pada budi daya tanaman sayuran organik. Produk pertanian yang dihasilkan warga didukung agar dapat secara 
luas dikenal dengan penambahan nilai tambah yang lebih baik dengan melakukan pelatihan pembuatan kemasan yang cantik dan menarik.

Kegiatan ini diharapkan dapat menjadi titik awal untuk terwujudnya desa mandiri energi dengan pemanfaatan kotoran sapi sebagai biogas. Biogas yang diproses dari kotoran ternak berhasil digunakan untuk pengganti gas LPG atau minyak tanah. Kegiatan ini juga diharapkan dapat mewujudkan pertanian terpadu di masyarakat berbasis penggunaan bahan-bahan lokal sehingga mengurangi biaya input pertanian seperti pupuk dan pestisida sintetik. Agar kegiatan ini dapat terus berkelanjutan, dan penerima nilai positif hasil biogas semakin banyak, perlu dibuat instalasi biogas-biogas yang lain di titik-titik peternakan sapi mandiri warga.

\section{UCAPAN TERIMA KASIH}

Ucapan terima kasih disampaikan kepada DRPM Kementerian Riset, Teknologi, dan Perguruan Tinggi atas dukungan dana melalui program hibah KKN-PPM tahun 2019, perangkat desa dan masyarakat Desa Sokawera, Kecamatan Cilongok, Kelompok Tani Qaryah Barokah Warohmah, serta mahasiswa KKN PPM Unsoed Desa Sokawera tahun 2019.

\section{DAFTAR PUSTAKA}

Artayana KCB, Kusuma IGBW, Adnyana IWB. 2017. Pengaruh variasi konverter biogas terhadap unjuk kerja pada mesin genset berkapasitas 1200 watt. Logic: Jurnal Rancang Bangun dan Teknologi. 14(3): 199-206.

Darmawan D. 2017. Pengaruh kemasan dan harga terhadap keputusan pembelian produk sayuran hidroponik. Agrimas. 1(1): 1-10. https://doi.org/10.31227/osf.io/vcsg3

Habibah, Wahdi A. 2019. Pemanfaatan limbah peternakan untuk pupuk organik sebagai sarana pemberdayaan usaha tani di kelompok wanita tani sri rejeki desa bentok darat, kecamatan bati-bati, kabupaten tanah laut. Pro Sejahtera. 1: 15-19.

Harsono SS. 2018. Inovasi teknologi pembuatan asap cair dari tempurung kelapa di Kabupaten Situbondo. Warta Pengabdian. 2(4): 157-169.

Juwito AF, Haryono T. 2013. Optimisasi energi terbarukan dalam pembangkitan energi listrik menuju desa mandiri energi di Desa
Margajaya. Jurnal Nasional Teknik Elektro dan Teknologi Informasi (JNTETI). 2(3): 40-48.

Kementerian ESDM. 2011. Handbook of Energy \& Economic Statistics of Indonesia. [Internet]. [Diakses Pada: 20 Maret 2020]. Tersedia pada: https://www.esdm.go.id/assets/media/cont ent/content-handbook-of-energy-economicstatistics-of-indonesia-2010-c19rfkq.pdf diakses 20 Maret 2020

Kementerian ESDM. 2018. Handbook of Energy and Economics Statistics of Indonesia. [Internet]. [Diakses Pada: 20 Maret 2020]. Tersedia pada: https://www.esdm.go.id/ assets/media/content/content-handbook-ofenergy-and-economic-statistics-of-indonesia2018-final-edition.pdf diakses 20 Maret 2020

Nugroho A, Aisyah I. 2013. Efektivitas asap cair dari limbah tempurung kelapa sebagai biopestisida benih di gudang penyimpanan. Jurnal Penelitian Hasil Hutan. 31(1): 1-8. https://doi.org/10.20886/jphh.2013.31.1.18

Oktavia I, Firmansyah A. 2016. Pemanfaatan teknologi biogas sebagai sumber bahan bakar alternatif di sekitar wilayah operasional PT. Pertamina EP Asset Prabumulih Field. Jurnal CARE; Jurnal Resolusi Konflik, CSR dan Pemberdayaan. 1(1): 32-36.

Pangestu EI, Suswanto, Supriyanto. 2014. Uji penggunaan asap cair tempurung kelapa dalam pengendalian Phytoptora sp. penyebab penyakit busuk buah kakao secara in vitro. Jurnal Perkebunan dan Lahan Tropika. 4(2): 39-44.

Profil Desa Sokaware. 2020. [Internet]. Diakses pada: 18 Desember 2019. Tersedia pada: http://sokawera-cilongok.desa.id/.

Semin AZM, Fathallah B, Cahyono IM, Ariana, Sutikno. 2014. Kajian pemanfaatan kotoran sapi sebagai bahan bakar biogas murah dan terbarukan untuk rumah tangga di boyolali. Sitekin. 11(2): 212-220.

Tim pengkajian bioindustri kelapa. 2015. Inovasi Teknologi Pembuatan Asap Cair dari Tempurung Kelapa. BPTP Riau (ID).

Widyastuti A, Berlian S, Afghani J. 2013. Karbon aktif dari limbah cangkang sawit sebagai adsorben gas dalam biogas hasil fermentasi anaerobik sampah organik. Jurnal Kimia Khatulistiwa. 2(1): 30-33. 